FESIEE

Fundación Emilio Soldevilla para la Investigación y Desarrollo

\section{Management Letters / Cuadernos de Gestión}

\author{
journal homepage: http://www.ehu.eus/cuadernosdegestion/revista/es/
}

ISSN: 1131-6837 / e-ISSN: 1988-2157

\title{
A bibliometric analysis of the literature on non-financial information reporting: Review of the research and network visualization
}

\author{
Análisis bibliométrico de la literatura sobre informes no financieros: revisión y visualización de redes \\ Melanie Grueso-Gala*, César Camisón Zornoza ${ }^{a}$ \\ a Despacho 1C07, Departamento de Dirección de Empresas, Facultad de Economía, Avinguda de Tarongers S/N 46022 Valencia (España). - cesar.camison@uv.es - https:// \\ orcid.org/0000-0001-8568-8825
}

* Corresponding author: Despacho 1P07, Departamento de Dirección de Empresas, Facultad de Economía, Avinguda de Tarongers S/N 46022 Valencia (España). - melanie.grueso@uv.es - https://orcid.org/0000-0002-9234-2248

\section{A R T I C L E I N F O}

Received 29 June 2021

Accepted 09 December 2021

Available online 10 February 2022

DOI: $10.5295 / \mathrm{cdg} .211545 \mathrm{mg}$

JEL: M14

\begin{abstract}
A B S T R A C T
This paper presents a bibliometric analysis of articles on the topic of non-financial information (NFI) reporting. The exponential growth over the last decade ( $90 \%$ of the articles were published in the last 10 years) indicates the relevance of the topic, but little is known about the structure and extent of research in this academic field. The purpose of this article is to provide a structured and up-to-date picture of the state of the art on the topic. We analyse the most relevant articles, authors, journals, countries and organizations. The analysis includes 3113 articles, collected from the Web of Science (WoS) Core Collection from 1970 - when the first two articles on the topic were published - to 2019. The software VOSviewer was used to graphically display the data. We identified and described a total of six research lines in the literature: determinants, essence, reports, integrated reporting, environment, and consequences of reporting. These research lines are analysed and gaps for future research are identified. We also comment on the implications of the strong collaboration networks found within Arab, European and Asian countries. This study is of great interest because it provides researchers with a map of the field, improving their understanding of the interconnection between aspects within the topic. It also enables researchers to better position their studies and to identify new streams of research.
\end{abstract}

Keywords: Non-Financial Information, Reporting, Bibliometric, Review, Sustainability, CSR.

\section{R E S U M E N}

Este artículo presenta un análisis bibliométrico de la literatura sobre informes no financieros (INF). El crecimiento exponencial durante la última década (el 90\% de los artículos sobre este tema de investigación fueron publicados en los últimos 10 años) indica la relevancia del mismo. No obstante, se sabe poco sobre la estructura y extensión de la investigación en este campo académico. El propósito de este artículo es brindar un estado del arte actualizado y estructurado sobre el tema. Analizamos los artículos, autores, revistas, países y organizaciones más relevantes. El análisis incluye un total de 3113 artículos, recopilados de la Colección principal de Web of Science (WoS) desde 1970, cuando se publicaron los dos primeros artículos sobre el tema, hasta 2019. Se utiliza el programa VOSviewer para mostrar gráficamente los datos. Identificamos y describimos un total de seis líneas de investigación en la literatura: los determinantes, la esencia, los informes, el informe integrado, el medio ambiente, y las consecuencias. Se analizan estas líneas de investigación y se sugieren ideas para futuras investigaciones. También se comentan las implicaciones de las importantes redes de colaboración encontradas dentro de países árabes, europeos y asiáticos. Este estudio es de gran interés ya que proporciona a los investigadores un mapa de este tema académico, mejorando la comprensión y conexión de los aspectos estudiados. También les permite posicionar sus estudios e identificar nuevas corrientes de investigación.

Palabras clave: Información No Financiera, Informes, Bibliométrico, Revisión, Sostenibilidad, RSC. 


\section{INTRODUCTION}

In recent decades, we have seen the emergence of certain trends stemming from the need for society as a whole to move towards sustainable development. Corporate social responsibility (CSR) is how companies contribute to sustainable development. Companies are no longer just trying to maximize their profits for the benefit of shareholders, but are also pursuing other goals. CSR comprises a broad set of actions in the economic, environmental and social spheres. Nowadays, more and more companies are carrying out actions in these areas.

Many national and international organizations (General Assembly of the United Nations 2012; European Parliament 2014) point out the importance of companies communicating their CSR actions to all their stakeholders, although the related reports and the information they contain have changed over the years. The disclosure of CSR actions is becoming increasingly important. Not only do businesses have to respect the environment or improve current social conditions, they also have to convey this to stakeholders. There is growing collective concern about labour conditions, as well as social and environmental issues, with a corresponding rise in the demand for CSR actions (Reverte 2009). Therefore, companies must not only carry out the actions, but also report them in order for interest groups to find out how their concerns are addressed by companies. Fifka (2013) explains that in the 1970s, businesses began to disclose some information about quality and social aspects in the annual report and in stand-alone reports. In the 1980s, empirical research on these voluntary disclosures started to emerge. In the 1990s, the focus of businesses and researchers was on environmental reports, but in the new millennium the social and environmental aspects were merged to form non-financial information (NFI) reports.

Due to the broad focus of CSR, there are a number of different terms (Cho and Patten 2007; Erkens et al. 2015; Sierra-Garcia et al. 2018) that refer to the documents where companies disclose their NFI, such as sustainability report or CSR report, among others (see Table 1). We believe that the term NFI encompasses the type of information disclosed in the aforementioned reports. Accordingly, in the present article, we use the term NFI reporting to refer to all such reporting. We adopt the definition provided Erkens et al. (2015), who present clear explanations and examples of what is understood by the term NFI. According to Erkens et al. (2015), there are two related academic approaches to NFI. The first and most commonly-used one focuses on the type of information disclosed. Under this approach, NFI reports seek to cover aspects such as CSR, strategy, corporate governance, and so on. They also reflect different measures of performance other than the traditional financial ones, such as job satisfaction, employee training and turnover, or customer satisfaction. The second approach focuses on where the information is disclosed. This approach interprets NFI as all the information disclosed outside (e.g., website, press releases, conferences, etc.) the traditional channel of communication (i.e., the annual report), even when it includes financial information. Erkens et al. (2015) elaborate on both aspects to provide a comprehensive definition of NFI. According to the authors NFI can be understood as "disclosure provided to outsiders of the organ- ization on dimensions of performance other than the traditional assessment of financial performance from the shareholders and debt-holders' viewpoint" (Erkens et al. 2015, p. 25). This includes aspects such as social and environmental matters, CSR and intellectual capital. It may be published either in a stand-alone report or in the company's annual report, but is always released outside the main financial statements (i.e., the balance sheet, the income statement, the statement of cash flows, the statement of changes in stockholders' equity and the notes). For instance, some forms of intellectual capital that are recognized in the accounts, such as $\mathrm{R} \& \mathrm{D}$ expenditure, would be considered financial information, while other forms, such as human capital, would be NFI.

Unlike financial information, there is no clear regulation of NFI reports governing aspects such as the rules they must follow, whether they should be assured, what content should be included, etc. This generates a degree of confusion among practitioners and researchers. To help address these issues, different international initiatives have emerged proposing guidelines. These include the UN Global Compact; the Global Reporting Initiative (GRI), which created the first global standards for reporting; or the International Integrated Reporting (IR) Council, which also created another type of corporate reporting. Governments have also committed to this challenge and are taking part by gradually introducing new laws, such as the European Union Directive 2014/95/EU, which encourages companies to present NFI. Due to this directive, each Member State is also adapting their legislation (Sierra-Garcia et al. 2018) to regulate which companies must disclose NFI.

These new challenges and the related regulatory changes have led to a growing literature on this topic. Many researchers have been attracted to conducting studies on the topic due to the increasing relevance of NFI for businesses.

NFI reporting can be considered a relatively new academic topic. As we see in the analyses conducted in the following sections, the first related article was published in 1970. Interest grew very slowly at first, with fewer than five publications per year. It was not until 2003 that the number of publications on the topic started to grow exponentially. There has been less than 20 years of intense growth in related research articles, which is a short time compared to other management/economic/finance topics. For instance, the academic field focusing on the concept of strategy first emerged in the early 1960s, and has grown rapidly since (Ronda-Pupo and Guerras-Martín 2012).

The recent exponential growth in the literature about NFI reporting is leading to the generation of unstructured knowledge. Little is known about the structure and extent of research in this academic field. Previous qualitative reviews (such as those by Ali et al. 2017; Dumay et al. 2016; or Fifka 2013, among others) offer some insights into specific aspects of the topic. However, Erkens et al. (2015), who analyse 33 review articles on the topic, point out that none of them are broad studies, meaning that they don't provide a holistic overview of the topic. Also, only a few of these reviews include tables, statistics or use bibliometrics. Qualitative reviews are indispensable for revealing the state of the art and discussing future developments; however, in terms of the method applied, they present various other problems (Vogel and Güttel 2013). They often suffer from subjectivity and are inherently biased. Moreover, the rapidly increasing number of publications 
on this topic exceeds the researcher's individual capacity to process a high quantity of information.

It is difficult to keep track of how the research field is evolving using only qualitative reviews. In order to be able to map the topic and provide a broad overview, there is a need for a complementary analysis that allows researchers to identify the structure underpinning all the knowledge generated to date on this subject.

Therefore, the objectives of the present study are: (1) to study the evolution of the topic and its main characteristics, namely, relevant authors, or most cited articles; (2) to identify the different lines of research on NFI reporting; and (3) to analyse each stream of research, describing its main contributions, relevant authors and main gaps.

A popular method for this purpose is bibliometric analysis. Bibliometric analyses use statistical and mathematical tools to analyse data and can be used in any discipline. This method also allows researchers to work with large samples of articles, which is useful for our purpose, as we aim to establish the structure of an entire topic and will thus have to manage a large number of articles. Furthermore, bibliometric analysis reveals interrelations among publications and provides researchers with information for organizing current contributions and detecting new lines for future research (Vogel and Güttel 2013; Merigó and Yang 2017; Ferreira 2018). While this method cannot provide the same level of detail as a qualitative review, it is a good complementary analysis as it enables the researcher to analyse a larger number of documents and provide information from a broader perspective. The use of visualization software for bibliometric studies (in this study, the VOSviewer program) facilitates the interpretation of the information provided by the different statistical analyses carried out.

We found only two previous English-language bibliometric analyses related to NFI reporting (Erkens et al. 2015; Fusco and Ricci 2019). Fusco and Ricci (2019) provide the structure of the literature on social and environmental accounting in the public sector: specifically, they focus on why, how and to whom public organizations report. This review is focused on the public sector and leaves out the private sector, thus omitting relevant issues concerning private sector organizations. Erkens et al. (2015) produce the first broad bibliometric analysis on the topic of NFI reporting, attempting to answer the key question: what is NFI? They provide a definition of what is considered NFI, which is the one we adopt in our study and use to draw up the list of keywords for our search strategy. However, we believe their analysis needs to be further developed in order to provide researchers with more useful and more detailed information.

Their article covers 787 publications from 1973 to 2013. However, from 2013 until 2019, the most recent year included in our analysis, 2232 articles were published, representing $71.7 \%$ of our sample. This is large number of publications that should be included in a topical analysis. Accordingly, one of our main contributions is providing a more up-to-date analysis in a field that is growing exponentially.

We also believe that the sample in the paper by Erkens et al. (2015) omits many potential articles because of the journals and search terms they use. They primarily search for data from accounting journals. They identified a total of 60 journals, of which 49 were accounting journals, compared to 6 "specialized" journals and 5 management journals; they then searched for NFI articles published in those journals. In our study, we control for the categories of the journals we want to search in (see methodology section for more details), but we do not specify the journals in advance, as this might lead to valuable journals being missed and a reduction in the number of articles in the sample. For instance, our analysis indicates that management is the category of journals that contributes the most articles, whereas according to Erkens et al. (2015) this is the least represented one.

In our opinion, the search terms could also be improved in order to better capture the articles on the topic. Erkens et al. (2015) used a total of 14 terms, compared to the 26 combined terms resulting from our set of keywords, as shown in Table 1.

Furthermore, our sample is not restricted to articles, so it does not leave out other types of contributions such as books or chapters; an omission which has been identified as a limitation in other studies (Fusco and Ricci 2019)

The structure of the topic provided by Erkens et al. (2015) needs to be further developed in order to be more useful for researchers. The authors analysed the article's title, abstract and keywords in their sample manually (without the use of any software) and listed a total of 10 research topics in the field of NFI. These topics are tested to see if they are statistically related to a specific methodology or journal type. However, the authors provide no description of and no insightful comments about the most relevant contributions in each one, leaving researchers with incomplete information about each of the topics identified.

Erkens et al. (2015) also exclude the analysis of references (citations and co-citations) from their study. This is indicated as a limitation in their article, as the analysis of citations (which we use in our study) can reveal important information about relationships among publications, authors, and so on.

These findings confirm the need for a broad, up-to-date bibliometric analysis that can structure all the previous literature on the topic and add valuable knowledge to previous reviews.

Our research analyses 3113 articles from 1970 to 2019. We collected data from the Web of Science (WoS) and used the VOSviewer software to graphically display the data. We employed tools such as keyword co-occurrence or bibliographic coupling. This is the first article on the topic of NFI reporting that combines a bibliometric analysis with the graphical visualization of the results.

The present study contributes to the literature on NFI reporting by structuring all the previous research and revealing the existence of six research lines. It also provides useful information about relevant contributions, authors or journals, and avenues for future research. This article is relevant because "having a map of the conceptual framework of a discipline can be of great interest in the pursuit of a holistic view of a field of study, improving our understanding of relationships between paradigms and the most analyzed topics and, thus, identifying essential work still to be done" (Ferreira et al. 2016, p. 727).

This study is useful to researchers in many ways. Junior researchers often find it hard to identify the main areas of research on a topic and the most relevant authors and articles in each re- 
search line. This study can help by providing them with this information for use in planning their research. Senior researchers can also benefit from a deeper understanding of how the field has evolved, more recent research lines, avenues for future research or how network collaborations among countries and organizations influence research.

Practitioners will also find it helpful to see the structure of the topic. It will facilitate the access to knowledge about any specific issue, which in turn can be applied to improve managerial practices regarding what and how to report, standards to follow, the relevance of external assurance, etc. Authorities will be able to better identify issues that may warrant regulation.

In the next section, we describe the methods and data that we used. Section 3 contains the results of the bibliometric analysis. In Section 4 we analyse the identified lines of research, and in Section 5 we find the discussion and outline the main conclusions.

\section{METHODOLOGY AND DATA}

For our analysis we collected data from the WoS Core Collection, which is an internationally-recognized source adhering to the highest standards. This database is commonly preferred in bibliometric studies (Garrigos-Simon et al. 2018; Mura et al. 2018; Gaviria-Marin et al. 2019; Seguí-Amortegui et al. 2019; Zhang et al. 2019; Bartolacci et al. 2020) as it includes more than 15,000 of the most relevant journals and contains more than 50,000,000 classified documents (Merigó and Yang 2017). It also provides all kind of useful metadata for these types of studies, such as titles, keywords, abstracts, references, authors, journals and citations, among others (Gaviria-Marin et al. 2019)

Due to the fact that authors use different terms when publishing about NFI reporting (Fifka 2013; Erkens et al. 2015; Sierra-Garcia et al. 2018) and that our aim is to capture and synthesise the research conducted over time in this topic, we have drawn up two sets of keywords. These words were selected manually from the literature and represent the most commonly-used terms referring to NFI reports. Table 1 shows the two sets of keywords:
Table 1

Sets of keywords used in our research

\begin{tabular}{cc}
\hline Set 1 & Set 2 \\
\hline $\begin{array}{c}\text { Non-financial information } \\
\text { Non-financial } \\
\text { Social }\end{array}$ & $\begin{array}{c}\text { Disclosure } \\
\text { Report }^{*}\end{array}$ \\
Social responsibility & \\
Environment* & \\
Sustainab & \\
CSR & \\
Corporate social responsibility \\
Corporate social \\
Corporate responsibility \\
Corporate governance \\
Corporate sustainability \\
Integrated
\end{tabular}

Note: We use the symbol ${ }^{\star}$ to include all the possible endings of a word, for example report* includes "report", "reports", "reporting" etc.

The two sets of keywords were combined in order to obtain all the possible terms that comprise our object of study. This gave us a total of 26 combinations that we entered into the field "topic" in WoS, which searches the title, abstract, and keywords of all the documents in the database.

The retrieval was done in October 2020, and it included all articles up to 2019, which was the last full year that we could obtain. The documents were filtered by categories including "Management", "Economics", "Business" and "Business finance". In total, 3113 documents have been included in our sample, with the following distribution: 1431 articles published in a journal classified in the "Management" research area, 1269 in "Business", 1189 in "Business Finance", and 538 in "Economics". These numbers do not sum up to 3113 because some journals can be classified in more than one research area.

Apart from articles, we also include in our sample other types of documents such as proceedings papers, books and book chapters. We consider them a significant part of the literature, containing relevant contributions. Fusco and Ricci (2019) identified the omission of these document types as a limitation of their bibliometric study; thus, we considered it appropriate to include them here.

The following diagram depicts the sample selection process.

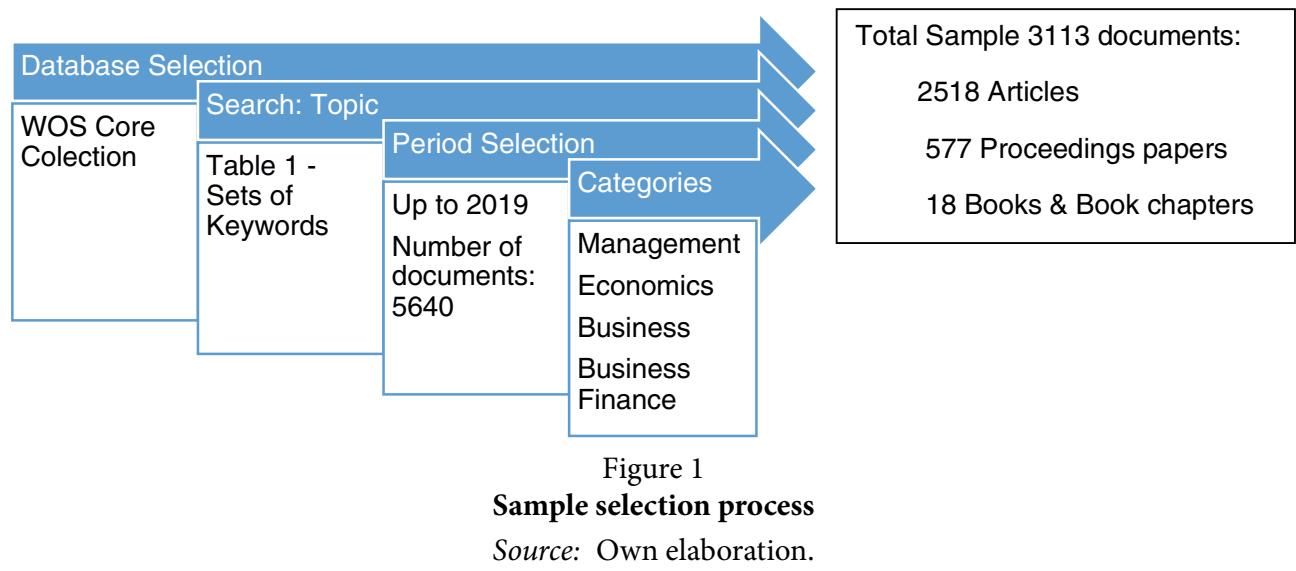


For the bibliometric analysis, we used the program VOSviewer 1.6.14. This software builds two-dimensional maps based on mathematical algorithms. It is used in other bibliometric studies (Castillo-Vergara et al. 2018; Garrigos-Simon et al. 2018; Seguí-Amortegui et al. 2019; Bartolacci et al. 2020) because it provides especially useful graphical representations with maps based on network data (Castillo-Vergara et al. 2018). It can show the structure and networks of different types of items such as authors, references, keywords, journals, organizations and countries; and through different types of links including co-authorship, co-occurrence, citation, bibliographic coupling and co-citation.

\section{RESULTS}

To obtain the most relevant information about the topic, we performed several analyses. For a general view of the evolution of NFI reporting, we start in subsection 3.1 by displaying information on the number of published papers. Secondly, we focus on the most cited articles, top authors and journals. The following subsections analyse the different maps created by VOSviewer, which start with a keyword co-occurrence analysis, followed by a bibliographic coupling of references and authors, and finally a co-authorship analysis of organizations and countries.

\subsection{Evolution of NFI reporting}

In 1970 the first two articles related to NFI reporting were published in WoS. Over the next 32 years, from 1970 to 2002, there was limited research on this topic, with fewer than five publications per year. Nevertheless, these numbers started to rise sharply in 2003, and particularly after 2009, when more than 100 papers were published annually. This increased to more than 200 in 2014, 300 in 2015, 400 in 2018, reaching almost 500 in 2019. The total number of articles is 3113 , of which $90 \%$ were published in the last 10 years. We can see in Figure 2 that researchers' interest in the topic has grown vertiginously over the last decade.

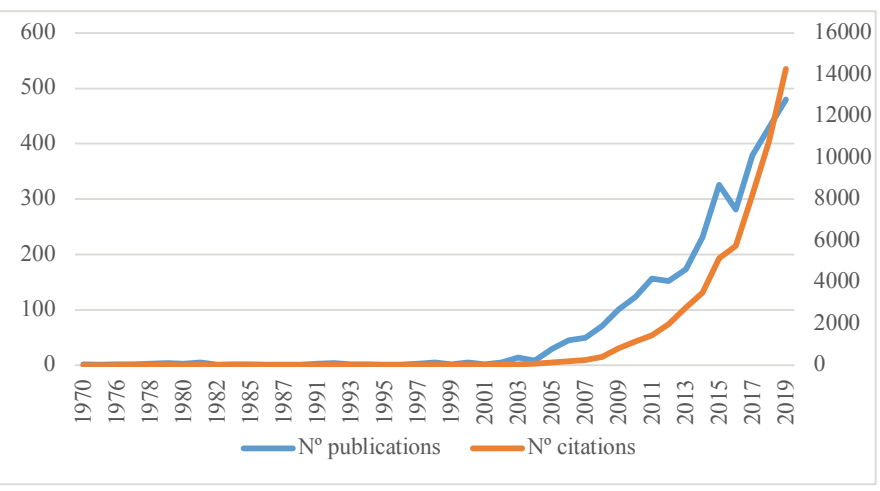

Figure 2

Annual publications and citations in WoS on NFI reporting

Note: The blue line shows the number of publications per year in WoS on the topic; the orange line indicates the annual citations. The axis on the left corresponds to the publications, and the axis on the right to citations.

Source: Own elaboration based on data from WoS 2020.
Regarding citations, the 3113 articles have a total of 57078 citations. The average number of citations is 18.34 per paper. We can see in Figure 2 that the number of citations has grown exponentially with the number of published articles.

\subsection{Top articles, authors and journals on NFI reporting}

In this section we can find the most relevant articles and authors on the topic. In Table 2 we can find the top 20 articles by number of citations, which is an indicator of the quality and influence of a paper (Blanco-Mesa et al. 2017; Garrigos-Simon et al. 2018).

In Figure 3 we can find the top authors by number of publications in order to gain an understanding of the most influential participants. The top 10 authors displayed in Figure 3 represent $7.35 \%$ of all the publications in the field, with a total of 229 published articles. The author that has contributed the most publications is Garcia-Sanchez, I.M. with 34 articles, representing $1.09 \%$ of the total. She is followed very closely by Patten, D.M with 31 publications (1\% of the total). In third and fourth place are Maroun, W. with 25 articles, and De Villers, C. with 24 .

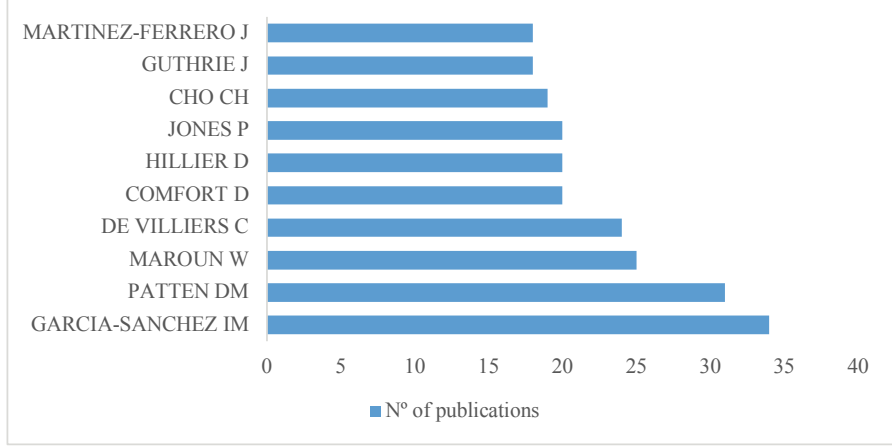

Figure 3

Publications by author

Source: Own elaboration based on data from WoS 2020.

Figure 4 shows the journals that publish the highest number of papers, with six journals standing out from the others. The first one is Journal of Business Ethics with 159 articles, representing $5.10 \%$ of the total. Corporate Social Responsibility and Environmental Management is the second one with 129 publications, followed by Social Responsibility Journal (115 publications), Accounting Auditing Accountability Journal (102 publications), Business Strategy and The Environment (87 publications), and Sustainability Accounting Management and Policy Journal (78 publications). These six journals represent $21.52 \%$ of the total articles published. 
Table 2

Top 20 articles with highest number of citations

\begin{tabular}{|c|c|c|c|c|c|c|}
\hline $\mathbf{R}$ & NC & Title & Journal & Authors & Year & Main outcomes \\
\hline 1 & 926 & $\begin{array}{c}\text { Towards the Sustainable } \\
\text { Corporation: Win-Win-Win } \\
\text { Business Strategies for Sustainable } \\
\text { Development }\end{array}$ & CMR & Elkington, J. & 1994 & $\begin{array}{l}\text { Pressures, strategies and disclosures } \\
\text { for sustainable development }\end{array}$ \\
\hline 2 & 868 & $\begin{array}{l}\text { Data in Search of a Theory: } \\
\text { A Critical Examination of the } \\
\text { Relationship Among Social } \\
\text { Performance, Social Disclosure and } \\
\text { Economic Performance of U.S. Firms }\end{array}$ & AMR & Ullmann, AA. & 1985 & $\begin{array}{l}\text { A theoretical framework is proposed } \\
\text { to improve empirical research. Focus } \\
\text { on social disclosure and performance }\end{array}$ \\
\hline 3 & 769 & $\begin{array}{l}\text { Determinants of corporate social- } \\
\text { responsibility disclosure: An } \\
\text { application of stakeholder theory }\end{array}$ & AOS & Roberts, R.W. & 1992 & $\begin{array}{c}\text { Stakeholder theory framework } \\
\text { (Ullman, AA., 1985) as a determinant } \\
\text { of CSR disclosure }\end{array}$ \\
\hline 4 & 731 & $\begin{array}{l}\text { Revisiting the relation between } \\
\text { environmental performance and } \\
\text { environmental disclosure: An } \\
\text { empirical analysis }\end{array}$ & AOS & $\begin{array}{c}\text { Clarkson, P.M.; Li, Y.; } \\
\text { Richardson, G.D.; Vasvari, } \\
\text { F.P. }\end{array}$ & 2008 & $\begin{array}{l}\text { Environmental performance as a } \\
\text { determinant of the level of voluntary } \\
\text { environmental disclosure }\end{array}$ \\
\hline 5 & 704 & $\begin{array}{l}\text { Voluntary Nonfinancial Disclosure } \\
\text { and the Cost of Equity Capital: } \\
\text { The Initiation of Corporate Social } \\
\text { Responsibility Reporting }\end{array}$ & $\mathrm{AR}$ & $\begin{array}{l}\text { Dhaliwal, D.S.; Li, O.Z.; } \\
\text { Tsang, A.; Yang, Y.G. }\end{array}$ & 2011 & $\begin{array}{c}\text { Economic consequences of CSR } \\
\text { reporting }\end{array}$ \\
\hline 6 & 645 & $\begin{array}{l}\text { Managing Public Impressions: } \\
\text { Environmental Disclosures in } \\
\text { Annual Reports }\end{array}$ & AOS & $\begin{array}{l}\text { Neu, D.; Warsame, H.; } \\
\text { Pedwell, K. }\end{array}$ & 1998 & $\begin{array}{c}\text { Stakeholder pressures as } \\
\text { determinants of environmental } \\
\text { disclosures }\end{array}$ \\
\hline
\end{tabular}

The relations among environmental disclosures, environmental

7643 performance, and economic performance: a simultaneous equations approach Christensen, T.E.; Hughes, 2004 K.E.
Good environmental performance is associated with good economic performance

The role of environmental

8566 disclosures as tools of legitimacy: research note

AOS Cho, C.H.; Patten, D.M. 2007

Environmental disclosure as a legitimizing tool

The level of disclosure in the

The relation between environmental

performance and environmental disclosure: a research note

AOS Patten, D.M.

2002

environmental report is affected by

the firm's environmental performance

\begin{tabular}{|c|c|c|c|c|c|c|}
\hline 10 & 427 & $\begin{array}{l}\text { Exposure, legitimacy, and social } \\
\text { disclosure }\end{array}$ & JAPP & Patten, D.M. & 1991 & $\begin{array}{l}\text { Public pressure as a determinant of } \\
\text { social disclosure }\end{array}$ \\
\hline 11 & 410 & $\begin{array}{l}\text { Corporate Communication and } \\
\text { Impression Management - New } \\
\text { Perspectives Why Companies Engage } \\
\text { in Corporate Social Reporting }\end{array}$ & JBE & Hooghiemstra, R. & 2000 & $\begin{array}{c}\text { Use of corporate social reporting as a } \\
\text { corporate communication instrument } \\
\text { to gain legitimacy }\end{array}$ \\
\hline 12 & 383 & $\begin{array}{l}\text { Assurance on Sustainability } \\
\text { Reports: An International } \\
\text { Comparison }\end{array}$ & $\mathrm{AR}$ & $\begin{array}{l}\text { Simnett, R.; Vanstraelen, A.; } \\
\text { Chua, W.F. }\end{array}$ & 2009 & $\begin{array}{l}\text { Voluntary assurance of sustainability } \\
\text { disclosure to enhance credibility }\end{array}$ \\
\hline 13 & 383 & $\begin{array}{l}\text { Social Accountability and } \\
\text { Corporate Greenwashing }\end{array}$ & JBE & Laufer, W.S. & 2003 & $\begin{array}{l}\text { Problems and challenges in ensuring } \\
\text { fair and accurate information on } \\
\text { reports }\end{array}$ \\
\hline 14 & 365 & $\begin{array}{l}\text { Corporate disclosures by family } \\
\text { firms }\end{array}$ & JAE & $\begin{array}{l}\text { Ali A.; Chen, T.Y.; } \\
\text { Radhakrishnan, S. }\end{array}$ & 2007 & $\begin{array}{l}\text { Type of information disclosed by } \\
\text { family firms due to ownership and } \\
\text { management characteristics }\end{array}$ \\
\hline
\end{tabular}




\begin{tabular}{|c|c|c|c|c|c|c|}
\hline $\mathbf{R}$ & NC & Title & Journal & Authors & Year & Main outcomes \\
\hline 15 & 365 & $\begin{array}{l}\text { The impact of corporate } \\
\text { characteristics on social- } \\
\text { responsibility disclosure: A typology } \\
\text { and frequency-based analysis }\end{array}$ & AOS & $\begin{array}{l}\text { Cowen, S.S.; Ferreri, L.B.; } \\
\text { Parker, L.D. }\end{array}$ & 1987 & $\begin{array}{l}\text { Correlation of firm characteristics } \\
\text { and types of disclosure }\end{array}$ \\
\hline 16 & 362 & $\begin{array}{c}\text { Nonfinancial Disclosure and } \\
\text { Analyst Forecast Accuracy: } \\
\text { International Evidence on } \\
\text { Corporate Social Responsibility } \\
\text { Disclosure }\end{array}$ & $\mathrm{AR}$ & $\begin{array}{c}\text { Dhaliwal, D.S.; } \\
\text { Radhakrishnan, S.; Tsang, A.; } \\
\text { Yang, Y.G. }\end{array}$ & 2012 & $\begin{array}{l}\text { Economic consequences of non- } \\
\text { financial reporting }\end{array}$ \\
\hline 17 & 355 & $\begin{array}{l}\text { Is accounting for sustainability } \\
\text { actually accounting for sustainability } \\
\text {.. and how would we know? } \\
\text { An exploration of narratives of } \\
\text { organisations and the planet }\end{array}$ & AOS & Gray, R. & 2010 & $\begin{array}{l}\text { Examination of the term } \\
\text { "sustainability" from an accounting } \\
\text { perspective }\end{array}$ \\
\hline 18 & 339 & $\begin{array}{l}\text { Determinants of Corporate Social } \\
\text { Responsibility Disclosure Ratings } \\
\text { by Spanish Listed Firms }\end{array}$ & JBE & Reverte, C. & 2009 & $\begin{array}{l}\text { Firm characteristics as determinants } \\
\text { of CSR reports }\end{array}$ \\
\hline 19 & 329 & $\begin{array}{l}\text { Getting to the Bottom of "Triple } \\
\text { Bottom Line" }\end{array}$ & BEQ & Norman, W.; MacDonald, C. & 2004 & $\begin{array}{c}\text { Critical review of "triple bottom line" } \\
\text { paradigm }\end{array}$ \\
\hline 20 & 306 & $\begin{array}{c}\text { Corporate Social Responsibility } \\
\text { Reporting in China: Symbol or } \\
\text { Substance? }\end{array}$ & OS & Marquis, C.; Qian, C.L. & 2014 & $\begin{array}{l}\text { Firms' dependence on the } \\
\text { government affects CSR report }\end{array}$ \\
\hline
\end{tabular}

Note: R: Ranking; NC: Number of Citations; CMR: California Management Review; AMR: Academy of Management Review; AOS: Accounting Organizations and Society; AR: Accounting Review; JAPP: Journal of Accounting and Public Policy; JBE: Journal of Business Ethics; JAE: Journal of Accounting and Economics; BEQ: Business Ethics Quarterly; OS: Organization Science.

Source: Own elaboration based on data from WoS 2020.

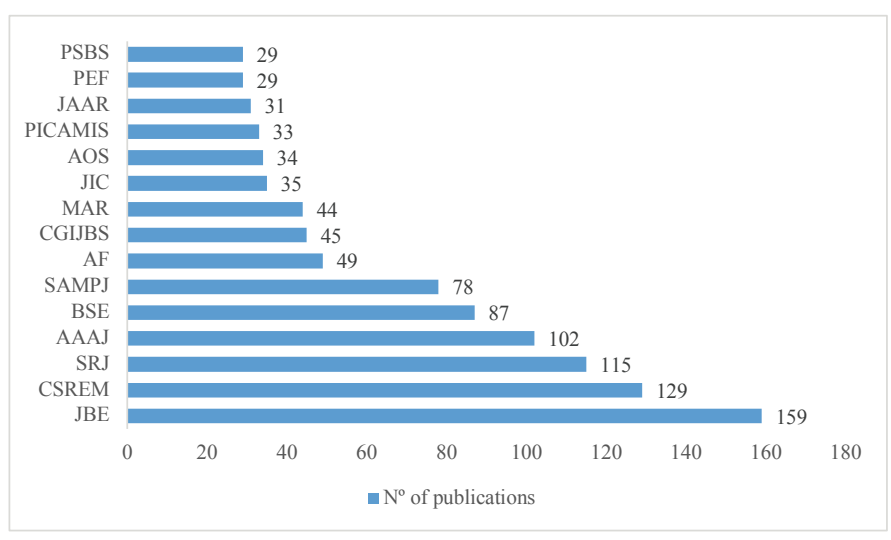

Figure 4

Publications by journal

Note: JBE: Journal of Business Ethics; CSREM: Corporate Social Responsibility and Environmental Management; SRJ: Social Responsibility Journal; AAAJ: Accounting Auditing Accountability Journal; BSE: Business Strategy and The Environment; SAMPJ:

Sustainability Accounting Management and Policy Journal; AF: Accounting Forum; CGIJBS: Corporate Governance The International Journal of Business in Society; MAR: Meditari Accountancy Research; JIC: Journal of Intellectual Capital; AOS: Accounting Organizations and Society; PICAMIS: Proceedings of the International Conference Accounting and Management Information Systems; JAAR: Journal of Applied Accounting Research; PEF: Procedia Economics and Finance; PSBS: Procedia Social and Behavioural Sciences.

Source: Own elaboration based on data from WoS 2020.

\subsection{Keyword co-occurrence analysis}

Keyword co-occurrence analysis is frequently used in bibliometric studies (Olczyk 2016; Garrigos-Simon et al. 2018; Dolhey 2019; Gaviria-Marin et al. 2019; Seguí-Amortegui et al. 2019). This analysis shows us the most frequent keywords and the relations between them (keywords that appear together in the same article).

For this analysis, we consider both author keywords (the terms that each author adds to their own article) and Keyword Plus, which are provided by a WoS algorithm (Garfield 1990; Li et al. 2009). In this way, a greater number of relevant papers are retrieved (Garfield 1990).

In Figure 5 below we can identify different nodes, each of which is a keyword. The size of the node determines the importance of a keyword (a large size means that the keyword is repeated more times). The relation between the nodes - the number of articles in which the linked keywords appear together- is shown by the distance and the size of the line that connects them (shorter distance and thicker lines mean a strong relationship).

As we can see in Figure 5, the program created four clusters: 


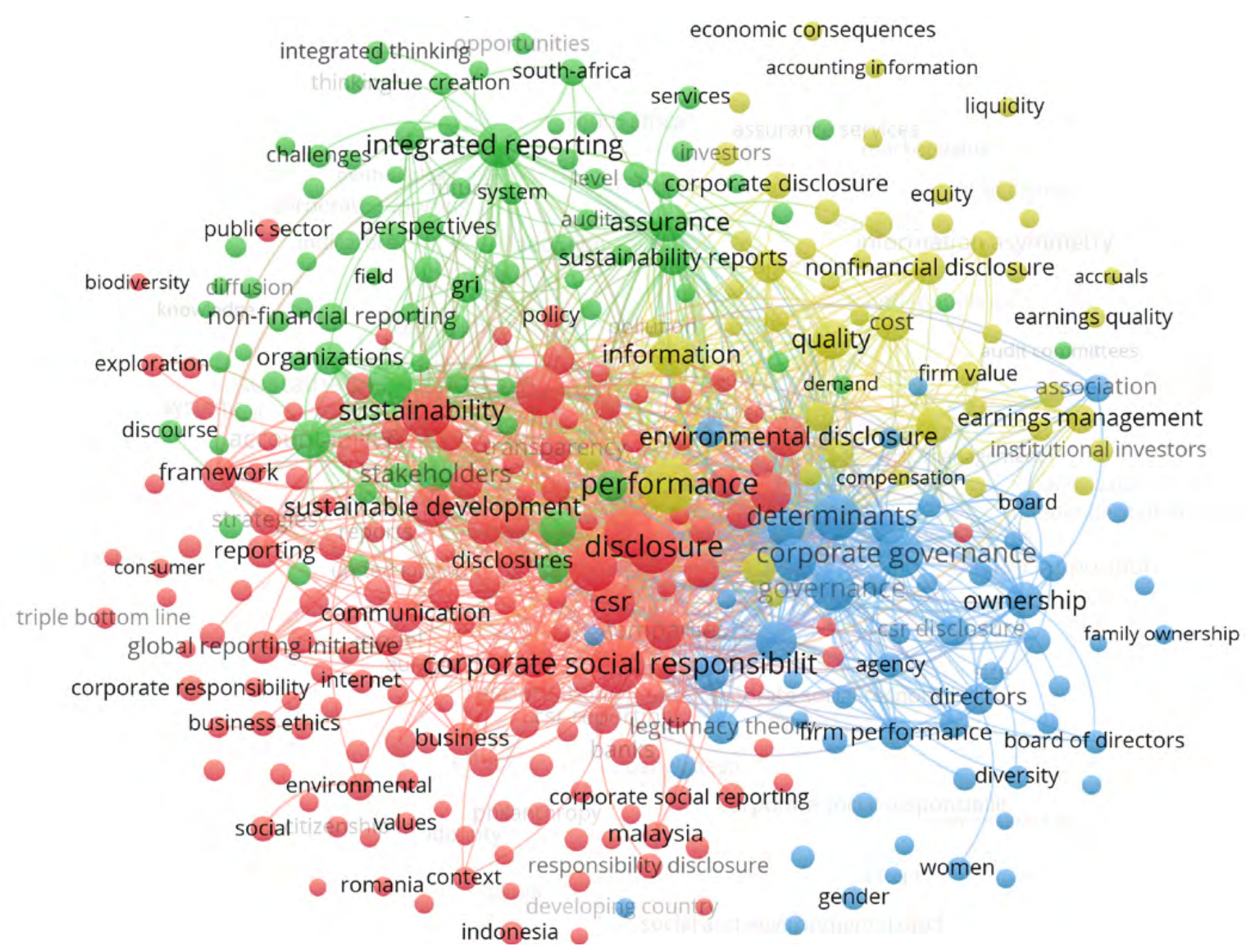

Figure 5

Keyword co-occurrence

Note: Considering 10 occurrences, the figure shows 349 of the 6001 existing keywords.

Source: Own elaboration based on data from WoS 2020.

The blue cluster comprises 56 keywords, of which "determinants" is one of the most important, with 332 occurrences. With this cluster we can identify one of the research lines on NFI reporting. Items such as "ownership" and "governance" are included in this cluster, which means that these variables have frequently been used when studying "determinants". We also find in Figure 5 other related aspects such as duality of the CEO, board diversity or gender. The most widely-used theories in articles on the determinants of NFI reporting are agency, legitimacy, socioemotional wealth, and stakeholder theories.

The yellow cluster is made up of 51 elements. "Performance" is the most notable item with 616 occurrences. In this cluster there is a wide range of financial terms ("economic consequences", "liquidity", "market value”, "equity", "growth", “investors”, "returns", etc).

In the red cluster, publications about NFI reports are related to "corporate social responsibility", "social", "environmental", "sustainable development", "business ethics", "values" and "phi- lanthropy" among others, which can be identified as the values or the 'essence' behind this type of practices.

In the green cluster, the terms that appear suggest a line of research focused on reporting practices, the different existing models of reporting (for example "integrated reporting"), and other related issues such as "assurance", "challenges", "perspectives", or "diffusion" among others. These terms focus not on the determinants of reporting, nor its consequences, but on aspects specifically involved in the NFI reports as an object of study.

\subsection{Bibliographic coupling of references and authors}

Bibliographic coupling is a type of citation analysis that assumes that two articles are similar when they cite the same references (Bartolacci et al. 2020). We chose to use this analysis because, as Vogel and Güttel (2013) explain, bibliographic coupling is useful for studying the "newstreams" in academia, which is important in order to set the agenda for new investigations. The 
distance between the nodes and the clusters shows us the networks created by the citation structure. This allows us to identify or confirm the streams of research on NFI reporting.

We have already shown in Table 2 the most cited articles. The present analysis helped us to corroborate the research lines identified in the keyword analysis, and identify which articles belong to each of the clusters. In Figure 6, we can identify these articles by the size of the nodes: the bigger the node, the more citations the article has. Such articles are present in the blue, yellow and red clusters, but there are none in the green cluster. This is due to the fact that this cluster is mostly made up of articles published in the last decade and have not yet been able to accumulate citations. This means that this cluster represents a fairly recent stream of research that is becoming popular among researchers. If we look at the articles belonging to this cluster, most of them focus on assurance (Dando and Swift 2003; Kolk and Perego 2010; O’Dwyer et al. 2011; Perego and Kolk 2012; Cohen and Simnett 2015) and specific types of report, especially IR (Brown and Dillard 2014; de Villiers et al. 2014; Adams 2015; Dumay et al. 2016). This result is in line with our findings from the keyword analysis.

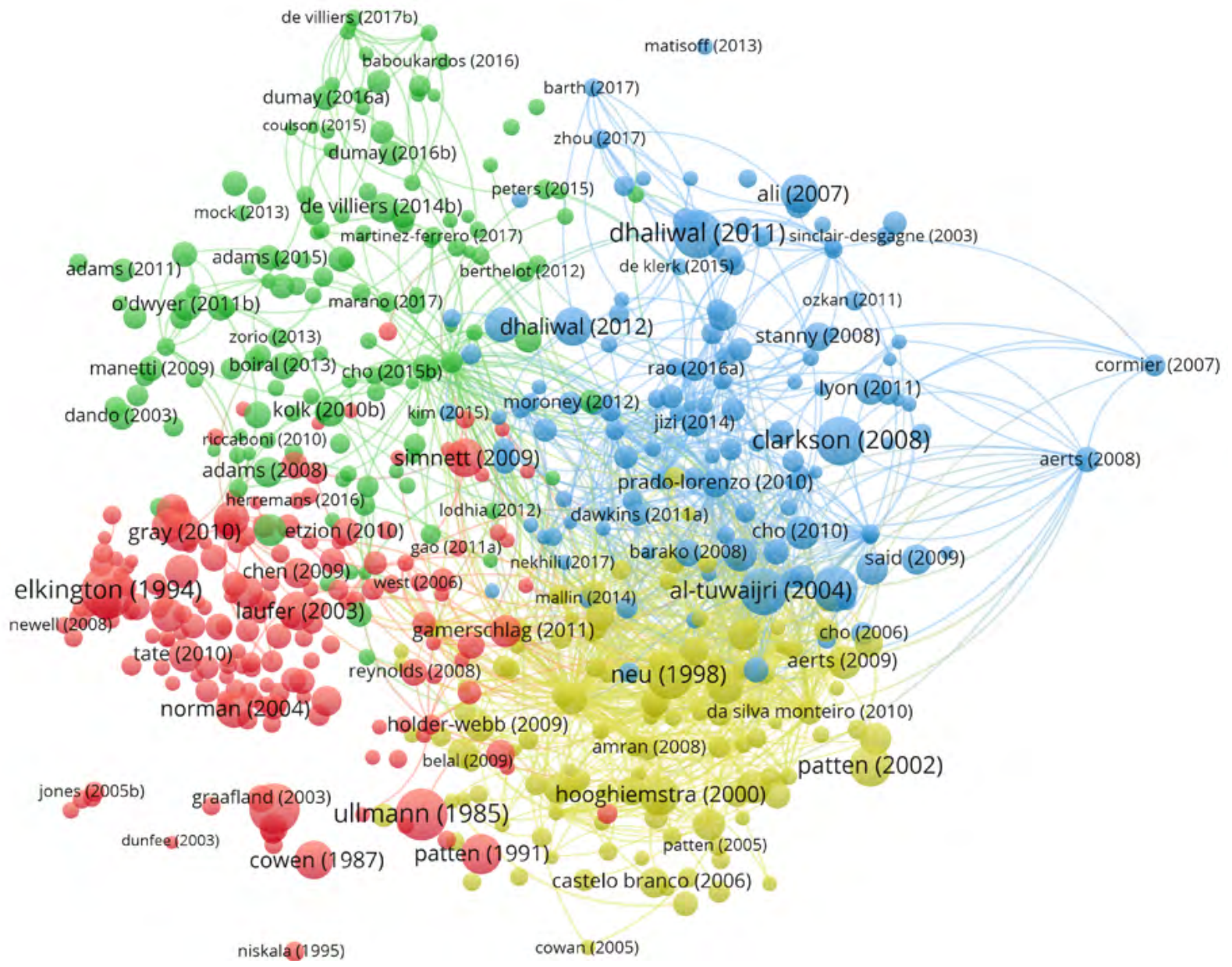

Figure 6

Bibliographic coupling of references

Note: Considering a minimum number of 25 citations, the figure shows 575 of the 3113 existing documents. Source: Own elaboration based on data from WoS 2020.

The article with the highest link strength in our analysis is by Fifka (2013). This article, located in the yellow cluster, is a review of empirical articles about the determinants of corporate responsibility reporting. Considering that the software organizes similar articles by cluster, we can establish that the yellow cluster is a group of publications mostly about the determinants of reporting, for instance Hooghiemstra (2000), Neu, Warsame, and Pedwell (1998) or Patten (2002).

Some of the most cited articles found in the blue cluster are Al-Tuwaijri, Christensen, and Hughes (2004), Dhaliwal et al. (2011) and Dhaliwal et al. (2012). We saw in Table 2 that these articles are focused on studying the economic consequences of NFI reporting.

Given the most cited articles in the red cluster (Ullmann 1985; Elkington 1994; Laufer 2003; Norman and MacDonald 2004; Gray 2010), we can state that it is a group belonging to the "essence" stream of research.

We have also studied the bibliographic coupling of authors. We use the same method for grouping items as in Figure 6, but this time each node represents an author. The groups of authors that appear together in the same cluster are related because they fre- 
quently cite the same references. In other words, they have similar research interests. Once we have the groups of authors, we can analyse their research interests and see if they correspond to one of the research lines we have already identified or if we have uncovered a new one. This analysis is also useful for identifying relevant authors that might specialize in one of the streams of research. The program detects four clusters, which we can see displayed in Figure 7.

The red cluster comprises 53 items. The two authors that have the highest link strength are Patten, D.M. and Cho, C.H. Looking at their publications, we find that their research specifically concerns the environment. Thus, we can say that this cluster represents a group of authors that have focused on studying NFI reporting with an environmental approach, including for example environmental disclosures and environmental performance.
The green cluster comprises 33 authors. The biggest nodes are De Villers, C., Maroun, W. and Dumay, J. Their research aims to study different aspects of IR. This is in line with our previous results indicating that one of the research lines is about types of NFI reporting. This analysis confirms that there is a growing body of authors studying this specific type of report, which marks it as a new research line.

The blue cluster includes 15 authors whose research is a mix of the different research lines identified. For instance, Garcia-Sanchez, I.M. whose research varies from determinants to IR, or assurance matters. This cluster doesn't identify a specific stream of research. Neither does the yellow cluster, which represents a residual cluster of 6 authors whose research focus on specific industries of the UK.

serafeim, george

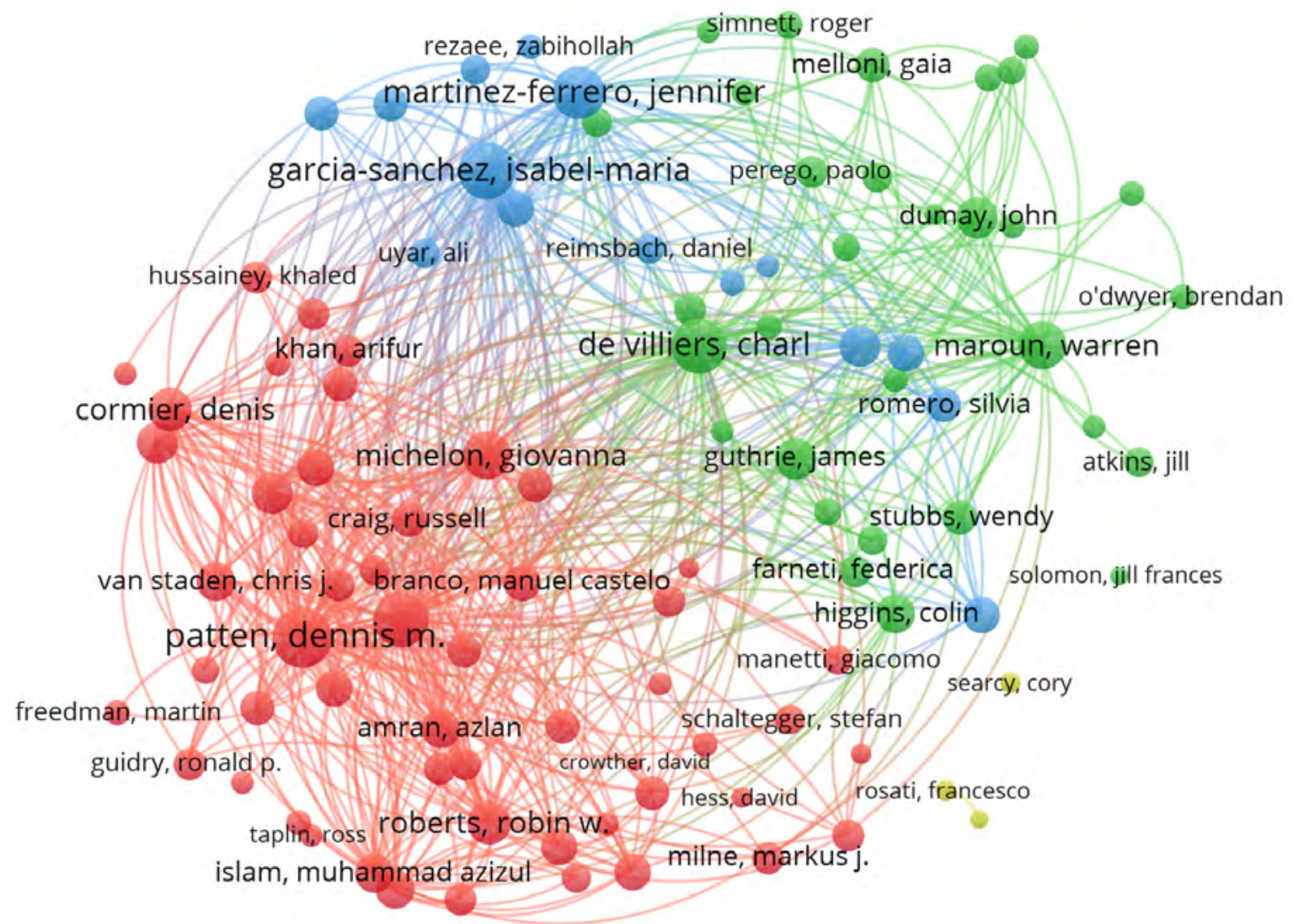

Figure 7

Bibliographic coupling of authors

Note: Considering a minimum number of 50 citations and 5 documents of an author, the figure shows 107 of the existing 5165 .

Source: Own elaboration based on data from WoS 2020. 


\subsection{Countries and organizations co-authorship analysis}

We finish our research on NFI reporting with the co-authorship analysis. This analysis is useful for displaying the collaboration networks on the topic. In this section, we see how the different countries and organizations work together. As in previous analyses, the size of the node indicates the importance of that item (in this case number of publications), while the distance reflects the degree of collaboration. The number of publications for each country is indicated by WoS based on the addresses that appear in each article. All addresses are considered, not just the first one listed. If there are multiple addresses for the same country in an article, they only count as one address.

Starting with the country analysis, according to the total link strength, England is the country that collaborates the most with other countries when publishing about NFI reporting.

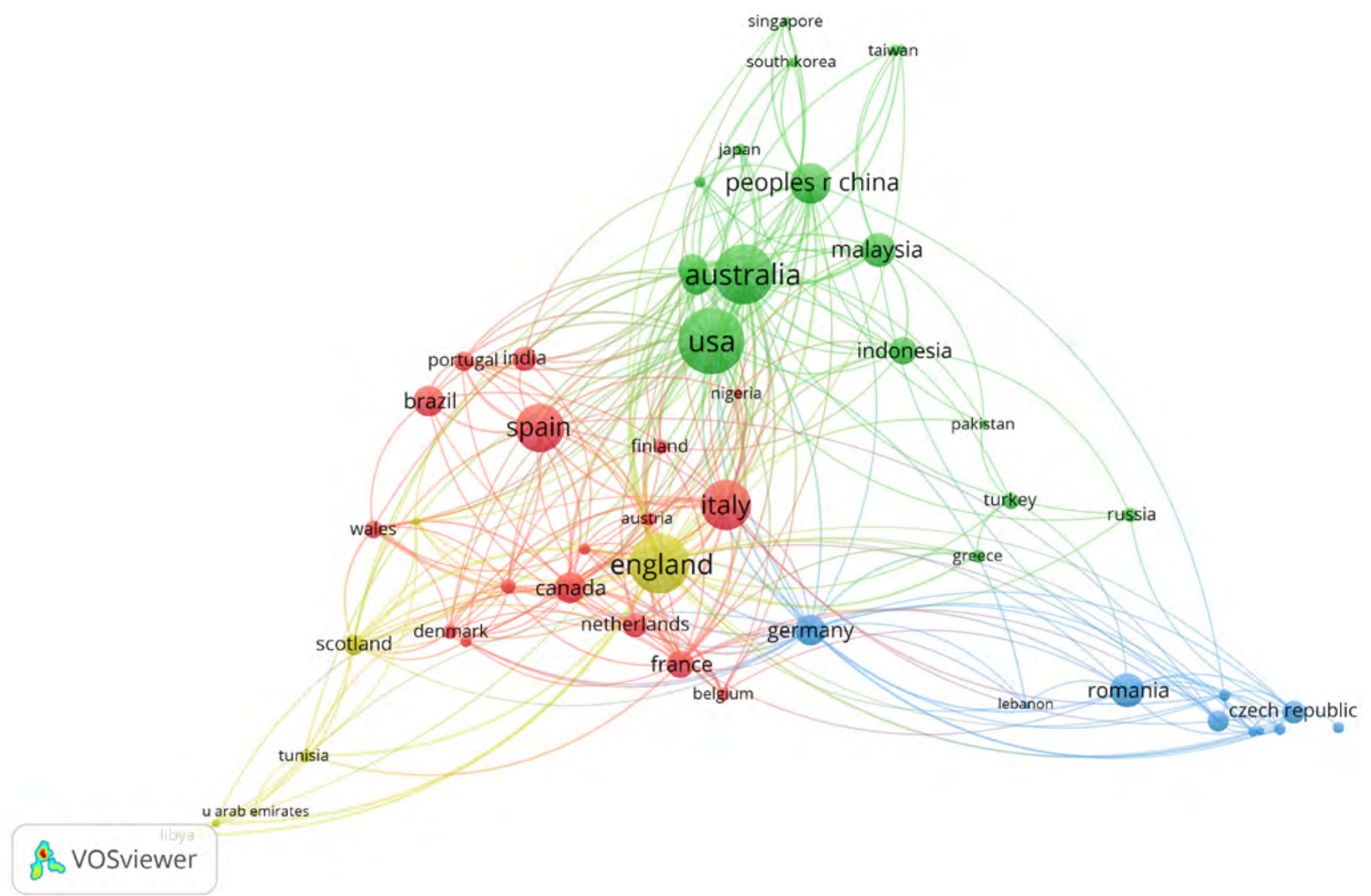

Figure 8

Co-authorship network of countries

Note: Considering a minimum number of 10 documents, the figure shows 51 of the 101 countries.

Source: Own elaboration based on data from WoS 2020.

The program created four clusters that we can see in Figure 8. The red cluster, with some exceptions, consists of European countries: Portugal, Spain, Italy, Denmark, France, Belgium, Netherlands, and Austria, among others. If we look at the distance between the items, the red cluster is the one located in the centre of the map, leaving the others marking three corners of a triangle. This means that these specific countries (in the red cluster) collaborate not only with the countries in their cluster, but also with the ones from outside.

In the green cluster, where we find the USA and Australia as the top publishing nations, we also find a group of countries that belong to the East Asian and Southeast Asian region: Singapore, South Korea, Taiwan, Japan, Bangladesh, China, Malaysia, and Indonesia. These countries are found close to each other, which means that they have a network of collaboration.

The blue and the yellow clusters also have small groups of countries belonging to the same region with a strong relationship of collaboration. In the yellow cluster we find Libya, Egypt, the Arab Emirates and Tunisia, which are all Arab countries. In the blue cluster, there is a group from Eastern Europe: the Czech Republic, Lithuania, Poland, Croatia, Slovakia, Ukraine, 
Romania and Estonia. These nodes are not big compared to others, but they show strong collaboration between them. It is worth noting that although most of these are European countries, they are located quite far from the red cluster, which represents the centre of the map. This means that there is no or little collaboration between Eastern Europe and other European countries.

Regarding the co-authorship analysis of organizations, we find in Figure 9 that the top ones by number of published documents are Bucharest University of Economic Studies in Romania with 60, University of Salamanca in Spain with 50, Macquarie University in Australia with 43, and University of Pretoria in
South Africa with 37 documents. However, the total link strength indicates that the ones that collaborate most with other organizations are University of Auckland, University of Pretoria, and Illinois State University.

There are several clusters, most of them occupying the centre of the map. The different clusters are made up of organizations from diverse countries. We find collaborations between organizations from New Zealand (Auckland University of Technology, University of Auckland, University of Waikato); Australia (Australian National University, University of South Australia), and Malaysia (Universiti Teknologi MARA, Universiti Sains Malaysia, University of Malaya) in the green cluster.

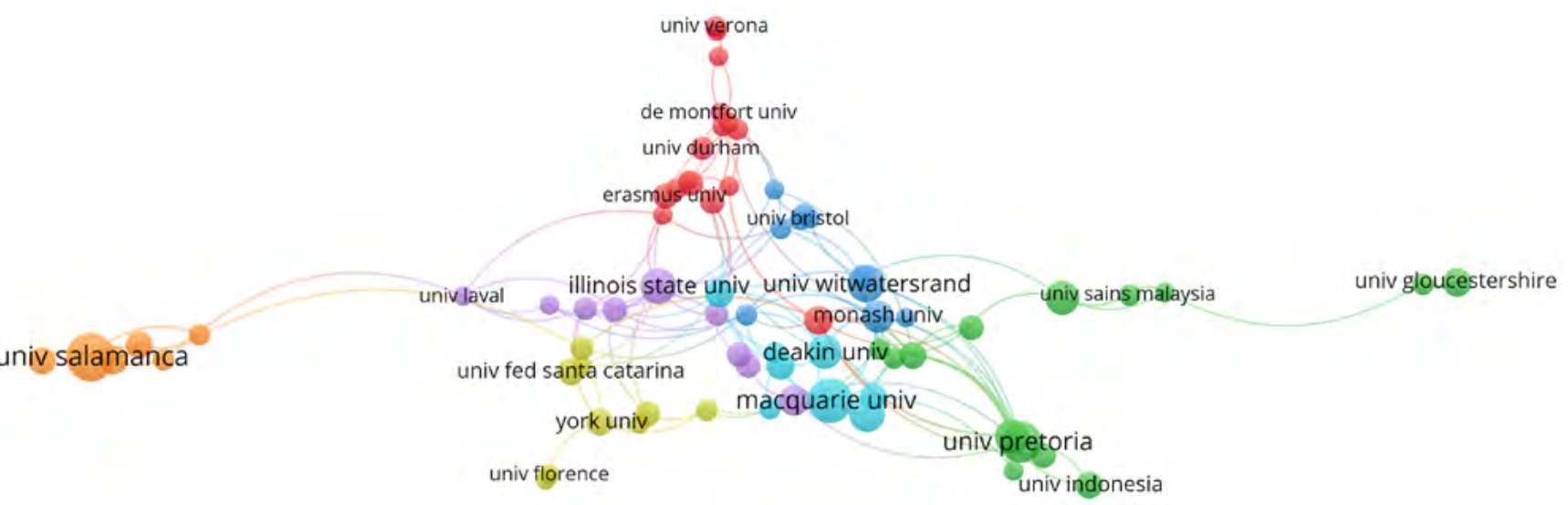

Vosviewer

Figure 9

Co-authorship network of organizations

Note: Considering a minimum number of 10 documents, the figure shows 73 of the 2117 organizations that exist.

Source: Own elaboration based on data from WoS 2020.

Other clusters show that organizations from England and the USA also collaborate: for instance, Illinois State University, University of Central Florida, University of Exeter and University of Reading, among others.

It is noteworthy that the only cluster with organizations all from the same country is the orange one. This cluster consists of six universities: University of Granada, University of Salamanca, University of Valencia, University of Zaragoza, University Jaume I, and University of the Basque Country, all of which are located in Spain. This means that these organizations strongly collaborate with one another, but the distance from the other items indicates that they engage in little collaboration with other organizations from outside the country.

\section{LINES OF RESEARCH ON THE TOPIC OF NFI REPOR- TING}

In light of the results from the analyses carried out, we identified six different research lines within the topic of NFI reporting. The first four groups emerged from the keyword co-occurrence analysis. Thanks to the bibliographic coupling of references, we could identify which articles belong to each one of them, allowing us to understand the interactions among researchers within the different research lines. The bibliographic coupling of authors revealed two more specific research streams on the topic. The six research lines identified are: 
1. The "essence" cluster. (Keywords: corporate social responsibility, social, environmental, sustainable development, triple bottom line, business ethics, values, and philanthropy, among others). The keywords that the cluster includes refer to the terms associated with the beginning of CSR, a practice necessarily linked to NFI reporting. The end of the last century saw the emergence of new perspective that businesses' responsibility goes beyond economic profit to include concepts such as business ethics, values or sustainable development. We labelled this research line the "essence" because no organization that seeks to protect the environment or disclose NFI information to their stakeholders lacks these values or ethical incentive. It refers to the inseparable condition underlying such practices: from the company's initial motivation to contribute to sustainable development, to the culmination of the process of issuing NFI reports.

This research line includes articles such as that by Elkington (1994), who highlights a business awakening on CSR and describes the stages that organizations move through (ignorance, awakening, denial) until they finally accept their responsibility (conversion and integration). The article points out the increasing pressures that businesses face, and states that they must play a central role in sustainable development. This group also includes articles addressing the complex relationship between stakeholder engagement and corporate responsibility (Greenwood 2007); or the triple bottom line paradigm, which holds that the success of businesses should be measured by their financial, social and environmental performance (Norman and MacDonald 2004).

2. The "determinants" cluster. (Keywords: determinants, ownership, board of directors, diversity, gender, women, CEO duality, agency, SEW, stakeholder, legitimacy). The keywords of this cluster refer to the study of the determinants of NFI reporting practices. Keywords such as "ownership", "directors", "governance", or "diversity" are included, which means that these variables have frequently been used when studying "determinants". In fact, ownership is found to be one of the most important drivers of NFI reports (Dienes et al. 2016). Authors that include these variables in their studies are Kiliç et al. (2015), Cucari et al. (2018), and Fernandez-Feijoo et al. (2014), among many others.

The paper with the highest link strength in the bibliographic coupling of reference analysis is by Fifka (2013), which is a review of empirical articles about the determinants of corporate responsibility reporting. The paper examines a total of 186 studies, providing a classification of determinants by geographical region/countries. The general conclusions drawn are that internal factors (such as size, industry, financial performance and managerial attitudes) have been studied more extensively than external factors (general political and socio-economic environment).

A more recent review article (Ali et al. 2017), indicates that for both, developed and developing countries, "company characteristics such as company size, industry sector, profitability, and corporate governance mechanisms predominantly appear to drive the CSR reporting agenda" (Ali et al. 2017, p. 289). In developing countries, international stakeholders (international media, foreign investors, etc.) have the most influence, while in developed countries it is the shareholders, creditors, investors, environmentalists and the media.

The keyword analysis also provides us with information regarding the application of theories. The most widely-used theories when researching determinants of NFI reporting are: agency (Bauwhede and Willekens 2008), legitimacy (Fernandez-Feijoo et al. 2018), socioemotional wealth (Cabeza-García et al. 2017; Arena and Michelon 2018), and stakeholder theories (Konrad et al. 2006; García-Sánchez et al. 2019; Torelli et al. 2020). Other theories that we found in the literature but which do not appear in the keyword analysis, probably because they are not so commonly used, are institutional theory (Garcia-Sanchez et al. 2016; Fernandez-Feijoo et al. 2019) and signalling theory (García-Benau et al. 2013). We also found that authors frequently use more than one theory, considering the different theories as complementary, to provide a more complete framework (Reverte 2009; Martínez-Ferrero et al. 2015; Odriozola and Baraibar-Diez 2017; Romero et al. 2018; Adel et al. 2019; Fusco and Ricci 2019).

3. The "reports" cluster. (Keywords: non-financial reporting, gri, integrated reporting, sustainability reports, perspectives, challenges, diffusion, assurance, discourse, etc.). The terms that appear suggest a line of research focused on reporting practices, the different existing models of reporting (for example "integrated reporting" or "gri"), and other related issues such as "assurance", "challenges", "perspectives", or "diffusion" among others. These terms focus on aspects specifically involved in the NFI reports as an object of study. The small size of the nodes in the bibliographic coupling of references indicate that this cluster is mostly made up of articles published in the last decade and have not yet been able to accumulate citations. This means that this cluster represents a fairly recent stream of research that is becoming popular among researchers.

NFI can be found in different locations and formats. The locations represent the vehicle through which it is transmitted to stakeholders. Generally, it can be found in the annual report outside the main financial statements, or in a separate report on the company's website. As we can see in Figure 5, special attention is given to the existing formats of reporting. There are different models or frameworks that organize how information should be disclosed, which aspects should be included, etc. The most well known and widely used are the GRI and the IR.

If we look at the articles belonging to this cluster, most of them focus on assurance (Dando and Swift 2003; Simnett et al. 2009; Kolk and Perego 2010; O’Dwyer et al. 2011; Perego and Kolk 2012; Cohen and Simnett 2015) and specific types of report, especially IR (Brown and Dillard 2014; de Villiers et al. 2014, 2017; Adams 2015; Dumay et al. 2016).

The disclosure of CSR information by organizations is not always met with trust from readers. Assurance of CSR reports is one way to gain credibility and legitimacy (Dando and Swift 2003; O'Dwyer et al. 2011). Some authors (Cohen and Simnett 2015) indicate areas which can benefit from further research; for instance, risk identification, materiality, ability to identify misstatements and fraud, evidence collection, and assurance reports and communication. We also find empirical articles that show how assurance practices are 
adopted (Perego and Kolk 2012), the determinants of such practices (Simnett et al. 2009; Kolk and Perego 2010) or the role of stakeholders in assurance processes in terms of being consulted and involved (Manetti 2012).

4. The "IR" cluster. There are no keywords to show in this cluster because it was not discovered in the keyword co-occurrence analysis, but in the author bibliographic coupling analysis. It revealed the existence of a relevant group of authors, such as de Villiers, C., or Dumay, J., who specialise in publishing articles about the new reporting framework, IR.

Dumay et al. (2016) indicates that the IR initiative is still in its very early stages, and there needs to be a debate about harmonization. The authors discuss the gap between academics and practitioners, suggesting the creation of international communities of leaders, practitioners, and policy-makers. They indicate that in order to improve, lessons have to be learnt from the GRI project (an older, successful framework for NFI reporting). Dumay et al. (2017) point out the barriers to implementing the IR framework, such as the lack of regulation and the existence of other relevant reporting frameworks. Also, there is a need for more specific metrics in IR. Despite these barriers, the authors also highlight the flexibility of the report, which can easily be adapted to comply with the EU Directive on non-financial disclosure (2014/95/EU).

De Villiers et al. (2014) suggest further research on the internal aspects of IR and propose a list of research questions for further research about the internal processes of the practice of IR. Measurement issues and control variables for research on IR are also noted by de Villiers et al. (2017).

5. The "consequences" cluster. (Keywords: performance, economic consequences, liquidity, market value, equity, growth, investors, returns, etc). We can see that when studying "performance" and the consequences of reporting, the main aim is to assess the economic impact, as there is a wide range of financial terms included. Many authors seek to establish whether the sustainability performance of an organization has any impact on economic variables such as the cost of equity, market value, or returns. (Gao et al. 2016; Barth et al. 2017; Miras-Rodríguez et al. 2015). The relationship between reporting practices and the cost of equity capital has been widely studied (Orens et al. 2010; Dhaliwal et al. 2011; Reverte 2012). However, a meta-analytic review (Souissi and Khlif 2012) shows that there are inconclusive empirical results on this relationship. The authors emphasize the importance of the legal and institutional environment when analysing the relationship between the aforementioned variables. The economic consequences of IR are also specifically studied, but again there are inconclusive results (Barth et al. 2017; Zhou et al. 2017). There is a need for more comparative studies between countries with different institutional environments in order to corroborate the findings associated with this specific type of report. We also observed that it is hard to find other non-economic variables among the keywords of the cluster. Other types of non-economic consequences of NFI reporting, such as reputational effects, should be studied.

6. The "environmental" cluster. As in the 'IR' cluster, there are no keywords because it was discovered in the author bibliographic coupling analysis. A group of authors focus on stud- ying issues such as environmental disclosures and environmental performance related to NFI reporting. Table 2 shows that some of the most cited articles are related to the environment (Patten 2002; Al-Tuwaijri et al. 2004; Cho and Patten 2007; Clarkson et al. 2008), all of which study environmental performance as a determinant of the level of environmental disclosure. These articles report mixed results regarding the sign of the relationship between the variables. According to legitimacy theory, companies with poor environmental performance are expected to provide more extensive environmental disclosures in order to gain legitimacy (Patten 2002; Cho and Patten 2007). On the contrary, findings from other articles (Al-Tuwaijri et al. 2004; Clarkson et al. 2008) support a positive relationship: "Superior environmental performers are more forthcoming in truly discretionary disclosure channels" (Clarkson et al. 2008, p. 325).

Patten, DM. is the most relevant author in the bibliographic coupling analysis. The author studies how poor environmental performers gain legitimacy through political activities (Cho et al. 2006), through environmental disclosures (Patten 2002; Cho and Patten 2007) and its reflection on environmental reputation (Cho et al. 2012). The author also studies the type of language that organizations employ on the reports depending on the level of performance (Cho et al. 2010). For instance, poor environmental performers exhibit more optimism and use less certain language.

\section{DISCUSSION AND CONCLUSION}

Using bibliometric techniques, this article has mapped and structured the literature of the field of NFI reporting. This paper is significant because, as far as we know, it is the first bibliometric analysis structuring NFI reporting literature.

The relevance of the topic is indicated by the exponential growth of the number of published articles. Even though this research topic first emerged in the 1970s, $90 \%$ of the articles have been published in the last 10 years, which indicates researchers' interest and the growing importance of the topic in the last decade.

The number of citations also reflects the relevance of the subject, with an average number of 18.34 citations per paper. Elkington (1994) and Ullmann (1985) published the most cited articles on the topic, with 926 and 868 citations, respectively. Both publications make important theoretical contributions. We also find Garcia-Sanchez, I.M., who has contributed the most publications, a total of 34 papers, representing $1.09 \%$ of the total.

The top journals in this field by number of published articles are Journal of Business Ethics with 159 articles (5.10\% of the total); Corporate Social Responsibility and Environmental Management with 129 publications; followed by Social Responsibility Journal (115 publications) in third place.

The analyses focusing on keyword co-occurrence and the bibliographic coupling of authors reveal a total of six research lines in the literature: the "essence", which focuses on business ethics and values underpinning NFI reporting practices; the "determinants", which are the drivers of these practices in organizations; the "reports", which analyses aspects regarding the models or standards of reporting, the assurance of reports, their 
diffusion, etc.; the "IR" and the "environment", which are both focused on aspects related to the specific type of report; and "consequences", which studies the effects of reporting on companies' cost of equity, liquidity, etc. In section 4 , the research lines are analysed in more detail, providing a brief summary of the most relevant contributions and gaps in each line.

Regarding the analysis of co-authorship relationships between countries, we find that the USA is the top contributing country, followed by Australia, England, Italy and Spain. European countries tend to collaborate frequently with other countries; specifically, England is the country that collaborates most. There are also three regional networks of strong collaboration (Arab countries; Eastern European countries; and East Asia and the Southeast Asian region). Another aspect worth noting in Figure 8 is the distance between the nodes, indicating that Eastern European countries engage in very little collaboration with other European countries.

This analysis reveals that some countries collaborate more than others. These collaboration networks could be explained by various different factors (Luukkonen et al. 1992) such as history, language and cultural similarity. Different clusters of countries have been identified in previous literature (Gupta et al. 2002), grouped according to cultural values and beliefs. In our study, we found strong regional collaborations networks within Arab countries, Eastern European and Asian countries, which are some of the cultural clusters identified by Gupta et al. (2002). In fact, the Eastern European countries are a clear example of a well-defined cultural cluster engaging in frequent and intensive collaborations (Luukkonen et al. 1992). The cultural environment can affect researchers, as they are part of society, thus affecting research outcomes (Hofstede 1994) and network collaborations.

Language could also be a reason why some countries collaborate more than others. Language is a barrier to publishing for researchers who are not native English-speakers (Gibbs 1995). To overcome this difficulty, they may collaborate with researchers from English-speaking countries (Koseoglu 2016). This could explain why England is the country that collaborates the most and that countries belonging to the Anglo cluster (Gupta et al. 2002) are the ones that publish the most, since the number of publications from each country reflects the number of articles in which authors from each nation have collaborated.

The formation of these collaboration clusters could be beneficial for creating knowledge. We have seen in the study of the determinants and consequences that some studies obtain different results when comparing countries. Collaboration networks do not necessarily imply multi-country analysis. However, collaboration is a way to access resources such as information and data sources (Koseoglu 2016). This will help researchers to conduct comparative studies among countries with information that they might not have been able to access otherwise. In this regard, collaboration networks might help to increase multi-country studies.

It is also important to note that many of the collaborations between countries are conducted within the same cultural cluster (Gupta et al. 2002). Hofstede (1994) analyses how each author's national culture can affect the outcomes of research. Combining authors from different cultures without having a single domi- nant researcher culture is important to eliminate cultural biases (Hofstede 1994). This underlines the relevance of collaborations among different culture clusters. It is also important to consider these cultural differences when conducting comparative studies. For example, Einwiller and Carroll (2020) show how NFI is disclosed differently in different cultural clusters: Germanic/Nordic European countries report more negative information in NFI reports, while Confucian Asian is the cluster that discloses the least negative information.

In the organization co-authorship analysis, we observe that Spanish universities engage in strong collaboration with one another but very little with other organizations from outside the country. This could be explained by the geographic proximity and the use of a common language, which are important factors in choosing collaborators (Larivière et al. 2006). Auckland University and Pretoria University are the ones that collaborate the most with other organizations, while the institutions that publish the most about NFI reporting are Bucharest University of Economic Studies in Romania and University of Salamanca in Spain.

The findings and conclusions that are extracted from the analysis in this paper can be useful for researchers, practitioners, and policy-makers. Focusing on researchers, the bibliometric analysis can help when starting an investigation on NFI reporting. The article presents the structure and main lines of research. It can also help in the search for specific relevant literature in the different streams of research as well as the main authors. This structure also points to promising future research avenues. Focusing on practitioners, the structure presented in this article will help them to easily access knowledge on issues that might be relevant to their organization. Although policy-makers are already gradually introducing new laws, such as the European Union Directive 2014/95/EU and its adoption in EU Member States, including Spain (Sierra-Garcia et al. 2018), they should pay attention to issues that researchers identify as relevant and might warrant regulation. The existing lack of legislation -incipient but still scarce- leaves many aspects unregulated, such as the above-mentioned assurance of reports.

Some future research avenues emerge from the set of analyses performed in this article:

First, more comparative studies between countries are needed in general. We observed in the study of the consequences that mixed results are reported, depending on the country where the research is performed. Furthermore, regarding the study of the determinants, Ali et al. (2017, p. 290) indicate that "the disclosure research on the national context in developing countries is dominated by single-country case studies and we still require a more fine-grained comparative analysis of disclosure in developing countries".

We corroborated this need with the countries co-authorship analysis. Most of the collaboration networks are between countries from the same cultural cluster (Gupta et al. 2002). In future studies, we suggest combining countries and/or researchers from different cultures to mitigate cultural bias (Hofstede 1994). In Figure 8, we also highlighted the lack of collaboration between Eastern European and other European countries. New studies could enrich the body of research by studying NFI reporting using data from both groups of countries, especially since most of them are governed by the same European legislative framework. 
Moreover, the European countries in the red cluster present a higher degree of economic development than the Eastern Europe countries. A collaboration between countries with these differences could be useful for many reasons: for instance, the businesses located in economies with different degrees of development could have different needs or challenges when reporting NFI; also, these different needs and challenges could help in the development of different types of reporting, as well as the creation of new laws in each country.

Second, the keyword analysis revealed that when investigating the consequences of reporting NFI, the focus is mainly on economic variables, such as cost of equity, market value, or liquidity. Thus, further research should examine other types of consequences, such as reputation.

Third, internal determinants such as size, industry, managerial attitudes and financial performance have been studied more extensively than external ones (Fifka 2013; Ali et al. 2017). Despite this, there are still some variables that call for more indepth study; for instance, researchers should examine "how the organizational culture and identity of the firm or the underlying psychological processes and decision-maker characteristics at the micro level influence CSR disclosure" (Ali et al. 2017, p. 290). Regarding external determinants, there is a need for studies that include stakeholder pressure, attitudes and perceptions.

Fourth, studies show that IR is still in its very early stages and that there is a gap between academics and practitioners (Dumay et al. 2016). Greater collaboration between the private sector and universities would help accelerate the progress made in the research and offer more practicable results (debate about harmonization, the inclusion of measures or indicators, etc).

Finally, we suggest performing a review of the literature in each of the analysed clusters. The objectives of this article were to identify the different streams of research and describe the most relevant contributions and authors in each one. This has helped us to identify some gaps within the clusters, which we propose as avenues for future research. However, we have not conducted an in-depth review of each cluster (as this was not our goal), which has undoubtedly meant that we have missed out many other important studies and current conversations within each line. Thus, we suggest conducting a review of the identified lines of research in order to establish their state of the art and future research avenues.

Several limitations should be mentioned. First, regarding the data source that we used, we only collected data from the WoS Core Collection. Although it includes the most relevant collection of articles, the analysis could include other databases such as Scopus or Google Scholar. Second, as it is based on statistical and mathematical tools, bibliometric methodology can produce confusing interpretations if it is not combined with other qualitative analyses.

\section{ACKNOWLEDGEMENTS}

The authors are grateful to Editor and two anonymous referees for suggestions and comments on previous version of the paper. This research was funded by the Ministry of Science, Innovation and Universities [grant number FPU17/04804]. Also, the project was developed within the framework of the UV Research Vice-Rector's own research program, call for special actions [reference UV-INV-AE-1554975]. Likewise, the project is funded by the State Plan for Scientific and Technical Research and Innovation 2017-2020 of the Ministry of Science and Innovation [reference PID2020-119642GB-I00].

\section{REFERENCES}

Adams, C.A., 2015. The international integrated reporting council: A call to action. Critical Perspectives on Accounting, 27, 23-28.

Adel, C., Hussain, M.M., Mohamed, E.K.A. and Basuony, M.A.K., 2019. Is corporate governance relevant to the quality of corporate social responsibility disclosure in large European companies? International Journal of Accounting and Information Management, 27(2), 301-332.

Al-Tuwaijri, S.A., Christensen, T.E. and Hughes, K.E., 2004. The relations among environmental disclosure, environmental performance, and economic performance: A simultaneous equations approach. Accounting, Organizations and Society, 29(5-6), 447-471.

Ali, A., Chen, T.Y. and Radhakrishnan, S., 2007. Corporate disclosures by family firms. Journal of Accounting and Economics, 44(1-2), 238-286.

Ali, W., Frynas, J.G. and Mahmood, Z., 2017. Determinants of Corporate Social Responsibility (CSR) Disclosure in Developed and Developing Countries: A Literature Review. Corporate Social Responsibility and Environmental Management, 24(4), 273-294.

Arena, C. and Michelon, G., 2018. A matter of control or identity? Family firms' environmental reporting decisions along the corporate life cycle. Business Strategy and the Environment, 27(8), 1596-1608.

Barth, M.E., Cahan, S.F., Chen, L. and Venter, E.R., 2017. The economic consequences associated with integrated report quality: Capital market and real effects. Accounting, Organizations and Society, 62, 43-64.

Bartolacci, F., Caputo, A. and Soverchia, M., 2020. Sustainability and financial performance of small and medium sized enterprises: A bibliometric and systematic literature review. Business Strategy and the Environment, 29(3), 1297-1309.

Bauwhede, H.V. and Willekens, M., 2008. Disclosure on corporate governance in the European union. Corporate Governance: An International Review, 16(2), 101-115.

Blanco-Mesa, F., Merigó, J.M. and Gil-Lafuente, A.M., 2017. Fuzzy decision making: A bibliometric-based review. Journal of Intelligent and Fuzzy Systems, 32(3), 2033-2050.

Brown, J. and Dillard, J., 2014. Integrated reporting: On the need for broadening out and opening up. Accounting, Auditing and Accountability Journal, 27(7), 1120-1156.

Cabeza-García, L., Sacristán-Navarro, M. and Gómez-Ansón, S., 2017. Family involvement and corporate social responsibility disclosure. Journal of Family Business Strategy, Elsevier, 8(2), 109-122.

Castillo-Vergara, M., Alvarez-Marin, A. and Placencio-Hidalgo, D., 2018. A bibliometric analysis of creativity in the field of business economics. Journal of Business Research, Elsevier, 85(March 2017), 1-9.

Cho, C.H., Guidry, R.P., Hageman, A.M. and Patten, D.M., 2012. Do actions speak louder than words? An empirical investigation of corporate environmental reputation. Accounting, Organizations and Society, 37(1), 14-25.

Cho, C.H. and Patten, D.M., 2007. The role of environmental disclosures as tools of legitimacy: A research note. Accounting, Organizations and Society, 32(7-8), 639-647.

Cho, C.H., Patten, D.M. and Roberts, R.W., 2006. Corporate Political Strategy: An Examination of the Relation between Political Expenditures, Environmental Performance, and Environmental Disclosure. Journal of Business Ethics, 67(2), 139-154. 
Cho, C.H., Roberts, R.W. and Patten, D.M., 2010. The language of US corporate environmental disclosure. Accounting, Organizations and Society, 35(4), 431-443.

Clarkson, P.M., Li, Y., Richardson, G.D. and Vasvari, F.P., 2008. Revisiting the relation between environmental performance and environmental disclosure: An empirical analysis. Accounting, Organizations and Society, 33(4-5), 303-327.

Cohen, J.R. and Simnett, R., 2015. CSR and assurance services: A research agenda. Auditing, 34(1), 59-74.

Cowen, S.S., Ferreri, L.B. and Parker, L.D., 1987. The impact of corporate characteristics on social responsibility disclosure: A typology and frequency-based analysis. Accounting, Organizations and Society, 12(2), 111-122.

Cucari, N., De Falco, S.E. and Orlando, B., 2018. Diversity of Board of Directors and Environmental Social Governance: Evidence from Italian Listed Companies. Corporate Social Responsibility and Environmental Management, 25, 250-266.

Dando, N. and Swift, T., 2003. Transparency and Assurance: Minding the Credibility Gap. Journal of Business Ethics, 44, 195-200.

de Villiers, C., Rinaldi, L. and Unerman, J., 2014. Integrated reporting: Insights, gaps and an agenda for future research. Accounting, Auditing and Accountability Journal, 27(7), 1042-1067.

de Villiers, C., Venter, E.R. and Hsiao, P.-C.K., 2017. Integrated reporting: Background, measurement issues, approaches and an agenda for future research. Accounting and Finance, 57(4), 937-959.

Dhaliwal, D., Li, O., Tsang, A. and Yang, Y., 2011. Voluntary Nonfinancial Disclosure and the Cost of Equity Capital: The Initiation of Corporate Social Responsibility Reporting. The Accounting Review, 86(1), 59-100.

Dhaliwal, D., Radhakrishnan, S., Tsang, A. and Yang, Y.G., 2012. Nonfinancial Disclosure and Analyst Forecast Accuracy: International Evidence on Corporate Social Responsibility Disclosure. The Accounting Review, 87(3), 723-759.

Dienes, D., Sassen, R. and Fischer, J., 2016. What are the drivers of sustainability reporting? A systematic review. Sustainability Accounting, Management and Policy Journal, 7 (2), 154-189.

Dolhey, S., 2019. A bibliometric analysis of research on entrepreneurial intentions from 2000 to 2018. Journal of Research in Marketing and Entrepreneurship, 21(2), 180-199.

Dumay, J., Bernardi, C., Guthrie, J. and Demartini, P., 2016. Integrated reporting: A structured literature review. Accounting Forum, 40(3), 166-185.

Dumay, J., Bernardi, C., Guthrie, J. and Torre, M. La., 2017. Barriers to implementing the International Integrated Reporting Framework A contemporary academic perspective. Meditari Accountancy Research, 25(4), 461-480.

Einwiller, S.A. and Carroll, C.E., 2020. Negative disclosures in corporate social responsibility reporting. Corporate Communications: An International Journal, 25 (2), 319-337.

Elkington, J., 1994. Towards the Sustainable Corporation: Win-WinWin Business Strategies for Sustainable Development. California Management Review, 36(2), 90-100.

Erkens, M., Paugam, L. and Stolowy, H., 2015. Non-financial information : State of the art and research perspectives based on a bibliometric study. Comptabilité - Contrôle - Audit, 3(21), 15-92.

European Parliament., 2014. DIRECTIVE 2014/95/EU OF THE EUROPEAN PARLIAMENT AND OF THE COUNCIL - of 22 October 2014 - amending Directive 2013/34/EU as regards disclosure of non-financial and diversity information by certain large undertakings and groups -. Official Journal of the European Union, available at: https://eur-lex.europa.eu/legal-content/EN/TXT/ PDF/?uri=CELEX:32014L0095\&from=EN (accessed 17 August 2020)
Fernandez-Feijoo, B., Romero, S and Ruiz-Blanco, S., 2014. Women on Boards: Do They Affect Sustainability Reporting? Corporate Social Responsibility and Environmental Management, 21, 351-364.

Fernandez-Feijoo, B., Romero, S. and Ruiz Blanco, S., 2019. Regional differences in industry specialization in the sustainability assurance market. Management Decision, 57(3), 669-687.

Fernandez-Feijoo, B., Romero, S. and Ruiz, S., 2018. Financial Auditor and Sustainability Reporting: Does it matter? Corporate Social Responsibility and Environmental Management, 25(3), 209-224.

Ferreira, F.A.F., 2018. Mapping the field of arts-based management: Bibliographic coupling and co-citation analyses. Journal of Business Research, 85(September 2015), 348-357.

Ferreira, J., Ferreira, F., Fernandes, C., Jalali, M., Raposo, M., and Marques, C., 2016. What do we (not) know about technology entrepreneurship research? International Entrepreneurship and Management Journal, 12(3), 713-733.

Fifka, M.S., 2013. Corporate Responsibility Reporting and its Determinants in Comparative Perspective - a Review of the Empirical Literature and a Meta-analysis. Business Strategy and the Environment, 22(1), 1-35.

Fusco, F. and Ricci, P., 2019. What is the stock of the situation? A bibliometric analysis on social and environmental accounting research in public sector. International Journal of Public Sector Management, 32(1), 21-41.

Gao, F., Dong, Y., Ni, C. and Fu, R., 2016. Determinants and Economic Consequences of Non-financial Disclosure Quality. European Accounting Review, 25(2), 287-317.

García-Benau, M.A., Sierra-Garcia, L. and Zorio, A., 2013. Financial crisis impact on sustainability reporting. Management Decision, 51(7), 1528-1542.

Garcia-Sanchez, I.M., Cuadrado-Ballesteros, B. and Frias-Aceituno, J.V., 2016. Impact of the Institutional Macro Context on the Voluntary Disclosure of CSR Information. Long Range Planning, 49(1), 15-35.

García-Sánchez, I.M., Hussain, N., Martínez-Ferrero, J. and Ruiz-Barbadillo, E., 2019. Impact of disclosure and assurance quality of corporate sustainability reports on access to finance. Corporate Social Responsibility and Environmental Management, 26(4), 832-848.

Garfield, E., 1990. Keywords Plus ISIs breakthrough retrieval method. Essays of an Information Scientist, 13, 295-299.

Garrigos-Simon, F.J., Narangajavana-Kaosiri, Y. and Lengua-Lengua, I., 2018. Tourism and sustainability: A bibliometric and visualization analysis. Sustainability, 10(6), 1-23.

Gaviria-Marin, M., Merigó, J.M. and Baier-Fuentes, H., 2019. Knowledge management: A global examination based on bibliometric analysis. Technological Forecasting and Social Change, 140(May 2018), 194-220.

General Assembly of the United Nations., 2012. The Future We Want. Rio+20 Conference, available at: https://www.un.org/ga/search/ view_doc.asp?symbol=A/RES/66/288\&Lang=E

Gibbs, W.W., 1995. Lost Science in the Third World. Scientific American, 273, 92-99.

Gray, R., 2010. Is accounting for sustainability actually accounting for sustainability...and how would we know? An exploration of narratives of organisations and the planet. Accounting, Organizations and Society, 35(1), 47-62.

Greenwood, M., 2007. Stakeholder engagement: Beyond the myth of corporate responsibility. Journal of Business Ethics, 74(4), 315-327.

Gupta, V., Hanges, P. and Dorfman, P., 2002. Cultural clusters: methodology and findings. Journal of World Business, 37, 11-15.

Hofstede, G., 1994. Management Scientists are Human. Management Science, 40 (1), 4-13.

Hooghiemstra, R., 2000. Corporate Communication and Impression Management - New Perspectives Why Companies Engage in Corporate Social Reporting. Journal of Business Ethics, 27(1/2), 55-68. 
Kiliç, M., Kuzey, C. and Uyar, A., 2015. The impact of ownership and board structure on Corporate Social Responsibility (CSR) reporting in the Turkish banking industry. Corporate Governance, 15(3), 357-374.

Kolk, A. and Perego, P., 2010. Determinants of the adoption of sustainability assurance statements: An international investigation. Business Strategy and the Environment, 19(3), 182-198.

Konrad, A., Steurer, R., Langer, M.E. and Martinuzzi, A., 2006. Empirical findings on business-society relations in Europe. Journal of Business Ethics, 63(1), 89-105.

Koseoglu, M.A., 2016. Growth and structure of authorship and co-authorship network in the strategic management realm: Evidence from the Strategic Management Journal. Business Research Quarterly, 19, 153-170.

Larivière, V., Gingras, Y. and Achambault, E., 2006. Canadian collaboration networks: A comparative analysis of the natural sciences, social sciences and the humanities. Scientometrics, 68 (3), 519-533.

Laufer, W.S., 2003. Social Accountability and Corporate Greenwashing. Journal of Business Ethics, 43(3), 253-261.

Li, L.L., Ding, G., Feng, N., Wang, M.H. and Ho, Y.S., 2009. Global stem cell research trend: Bibliometric analysis as a tool for mapping of trends from 1991 to 2006. Scientometrics, 80(1), 39-58.

Luukkonen, T., Persson, O. and Sivertsen, G., 1992. Understanding Patterns of International Scientific Collaboration. Science, Technology \& Human Values, 17(1), 101-126.

Manetti, G., 2012. The Role of Stakeholders in Sustainability Reporting Assurance. Journal of Business Ethics, 107(3), 363-377.

Marquis, C. and Qian, C.L., 2014. Corporate Social Responsibility Reporting in China: Symbol or Substance? Organization Science, 25 (1), 127-148.

Martínez-Ferrero, J., Garcia-Sanchez, I.M. and Cuadrado-Ballesteros, B., 2015. Effect of financial reporting quality on sustainability information disclosure. Corporate Social Responsibility and Environmental Management, 22(1), 45-64.

Merigó, J.M. and Yang, J.B., 2017. Accounting Research: A Bibliometric Analysis. Australian Accounting Review, 27(1), 71-100.

Miras-Rodríguez, M.M., Carrasco-Gallego, A. and Escobar-Pérez, B., 2015. Has the CSR engagement of electrical companies had an effect on their performance? A closer look at the environment. Business strategy and the Environment, 24, 819-835.

Mura, M., Longo, M., Micheli, P. and Bolzani, D., 2018. The Evolution of Sustainability Measurement Research. International Journal of Management Reviews, 20(3), 661-695.

Neu, D., Warsame, H. and Pedwell, K., 1998. Managing Public Impressions: Environmental Disclosures in Annual Reports. Accounting, Organizations and Society, 23(3), 265-282.

Norman, W. and MacDonald, C., 2004. Getting to the Bottom of "Triple Bottom Line". Business Ethics Quarterly, 14(2), 243-262.

O'Dwyer, B., Owen, D. and Unerman, J., 2011. Seeking legitimacy for new assurance forms: The case of assurance on sustainability reporting. Accounting, Organizations and Society, 36(1), 31-52.

Odriozola, M.D. and Baraibar-Diez, E., 2017. Is Corporate Reputation Associated with Quality of CSR Reporting? Evidence from Spain. Cor porate Social Responsibility and Environmental Management, 24(2), 121-132.

Olczyk, M., 2016. A systematic retrieval of international competitiveness literature: a bibliometric study. Eurasian Economic Review, 6(3), 429-457.
Orens, R., Aerts, W. and Cormier, D., 2010. Web-Based Non-Financial Disclosure and Cost of Finance. Journal of Business Finance \& Accounting, 37(9-10), 1057-1093.

Patten, D.M., 2002. The relation between environmental performance and environmental disclosure: A research note. Accounting, Organizations and Society, 27(8), 763-773.

Patten, D.M., 1991. Exposure, legitimacy, and social disclosure. Journal of Accounting and Public Policy, 10(4), 297-308.

Perego, P. and Kolk, A., 2012. Multinationals' Accountability on Sustainability: The Evolution of Third-party Assurance of Sustainability Reports. Journal of Business Ethics, 110(2), 173-190.

Reverte, C., 2009. Determinants of corporate social responsibility disclosure ratings by Spanish listed firms. Journal of Business Ethics, 88(2), 351-366.

Reverte, C., 2012. The Impact of Better Corporate Social Responsibility Disclosure on the Cost of Equity Capital. Corporate Social Responsibility and Environmental Management, 19(5), 253-272.

Roberts, R.W., 1992. Determinants of corporate social responsibility disclosure: An application of stakeholder theory. Accounting, Organizations and Society, 17(6), 595-612.

Romero, S., Ruiz, S. and Fernandez-Feijoo, B., 2018. Sustainability reporting and stakeholder engagement in spain: Different instruments, different quality. Business Strategy and the Environment, 28(1), 221-232.

Ronda-Pupo, G.A. and Guerras-Martín, L.A., 2012. Dynamics of the evolution of the strategy concept 1962-2008: A co-word analysis. Strategic Management Journal, 33(2), 162-188.

Seguí-Amortegui, L., Clemente-Almendros, J.A., Medina, R. and Grueso-Gala, M., 2019. Sustainability and competitiveness in the tourism industry and tourist destinations: A bibliometric study. Sustainability, 11(22)

Sierra-Garcia, L., Garcia-Benau, M.A. and Bollas-Araya, H.M., 2018. Empirical Analysis of Non-Financial Reporting by Spanish Companies. Administrative Sciences, 8(3), 29.

Simnett, R., Vanstraelen, A. and Fong Chua, W., 2009. Assurance on Sustainability Reports: An International Comparison. The Accounting Review, 84(3), 937-967.

Souissi, M. and Khlif, H., 2012. Meta-analytic review of disclosure level and cost of equity capital. International Journal of Accounting \& Information Management, 20(1), 49-62.

Torelli, R., Balluchi, F. and Furlotti, K., 2020. The materiality assessment and stakeholder engagement: A content analysis of sustainability reports. Corporate Social Responsibility and Environmental Management, 27(2), 470-484.

Ullmann, A.A., 1985. Data in Search of a Theory: A Critical Examination of the Relationships among Social Performance, Social Disclosure, and Economic Performance of U. S. Firms. The Academy of Management Review, 10(3), 540-557.

Vogel, R. and Güttel, W.H., 2013. The Dynamic Capability View in Strategic Management: A Bibliometric Review. International Journal of Management Reviews, 15(4), 426-446.

Zhang, D., Zhang, Z. and Managi, S., 2019. A bibliometric analysis on green finance: Current status, development, and future directions. Finance Research Letters, Elsevier, 29(January), 425-430.

Zhou, S., Simnett, R., Green, W., Bradbury, M., Cohen, J., Easton, P., Johnstone, K., et al. 2017. Does Integrated Reporting Matter to the Capital Market? ABACUS, 53(1), 94-132. 